\title{
ANALISIS ESTIMASI BIAYA DENGAN METODE COST SIGNIFICANT MODEL SEBAGAI DASAR PERHITUNGAN KONSTRUKSI JEMBATAN BETON BERTULANG DI KABUPATEN ACEH TAMIANG
}

\author{
Khamistan \\ Program SarjanaTerapan Teknologi Rekayasa Konstruksi Jalan dan Jembatan \\ Jurusan TeknikSipil, PoliteknikNegeri Lhokseumawe \\ Jl.BandaAceh-MedanKm.280 Buket rata \\ Email:khamistankm@yahoo.com
}

DOI: http://dx.doi.org/10.29103/tj.v8i2.168

\begin{abstract}
Abstrak
Salah satu elemen penting dalam proyek adalah tahap estimasi biaya. Sering kali saat proyek masih pada tahap awal ,informasi untuk mengestimasi belum terlalu detail, sehingga hasil estimasi cenderung tidak begitu akurat, oleh karena itu dibutuhkan model estimasi biaya yang dapat menjelaskan sebagian besar proyek berdasarkan informasi yang sesedikit mungkin. Metode estimasi yang digunakan adalah Cost Significant Model, model ini menggunakan biaya pekerjaan yang secara signifikan berpengaruh terhadap biaya total proyek. Tujuannya adalah untuk mengetahui tingkat keakuratan model estimasi biaya pada pembangunan jembatan beton bertulang terhadap biaya actual proyek. Data dihimpun dengan menggunakan metode sampling dan diperoleh berupa 5 paket proyek konstruksi jembatan beton bertulang dari tahun 2013 sampai 2017. Dengan hasil yang didapatkan berupa persamaan model estimasi yaitu Y=-19.832.201,418+1,948X1 +0,889X2 +4,274X3, dengan Cost Model Factor sebesar 0,9844. Tingkat keakuratan hasil estimasi berkisar antara $-3,37 \%$ sampai $+1,69 \%$. Dilihat dari persentase keakuratan hasil estimasi tersebut, $A A C E$ International menunjukkan model ini dapat digunakan untuk pengecekan perkiraan penawaran.
\end{abstract}

Kata kunci: Estimasi, jembatan, cost significant model

\begin{abstract}
One of the important element is cost estimation.Usually when the project is still at its early step, the information required for estimation are not really detail which makes the estimation's result is inaccurate.There fore, it's been required a cost estimation method that capable to explaining the whole project based on the limited information. The method which used is Cost Significant Model, this kind of model used the cost of the works that significantly influenced to ward the total project cost. The function of this method is knowing the cost estimation's accuracy of reinforced-concrete bridge bymethod Cost Significant Model to ward actual project cost. The data were collected using the sampling method and obtained 5 packages data of reinforced concrete bridge constructions project since 2013 to2017. The result which obtained is the estimation's model equestion $Y=-19.832 .201,418+1,948 X 1+0,889 X 2+4,274 X 3$, with Cost Model Factoris 0.9844. the accuracy of estimations results are among$3.37 \%$ to $+1.69 \%$. Seen from the accuracy percentages of estimation's resultit self, $A A C E$ International a vowing that this model can beuse to examining tender estimation.
\end{abstract}

Keywords: Estimation, bridge, cost significant model

Analisis Estimasi Biaya Dengan Metode Cost Significant Model Sebagai Dasar Perhitungan Konstruksi Jembatan Beton Bertulang Di Kabupaten Aceh Tamiaang - 


\section{Latar Belakang}

Peranan jembatan dalam bidang perekonomian di Kabupaten Aceh Tamiang cukup penting, terutama dalam memperlancar hubungan antara pusat produksi dengan daerah pemasaran. Dengan adanya pembangunan jembatan diharapkan roda perekonomian akan berjalan dengan baik dan lancar.

Dalam pembangunan jembatan, estimasi biaya memegang peranan penting dalam penyelenggaraan proyek konstruksi, di mana dalam pelaksanaan praktik konstruksi dibutuhkan beberapa macam estimasi yang berbeda di dasarkan dari tujuan penggunaan dan peruntukannya. Tahap awal perencanaan proyek pembangunan jembatan, seperti pada saat penyusunan anggaran proyek, jelas estimasi tidak mungkin didasarkan pada perhitungan kuantitas (volume) pekerjaan karena uraian dan spesifikasi pekerjaan belum tersusun. Hal yang penting dalam membuat model estimasi biaya pada tahap awal perencanaan proyek adalah harus mudah dalam penggunaannya, akurat dan menghasilkan estimasi yang dapat dipertanggungjawabkan. Maka dengan metode Cost SignificantModel yang akan dikembangkan dalam penelitian ini diharapkan member jawaban tuntutan akan tersedianya estimasi biaya awal proyek pembangunan jembatan beton bertulang di Kabupaten Aceh Tamiang.

Untuk menjawab permasalahan di atas maka dirumuskan pokok permasalahan yaitu:

a. Sub pekerjaan apakah yang berpengaruh secara signifikan terhadap biaya total proyek.

b. Bagaimana penggunaan metode Cost Significant Model pada proyek jembatan beton bertulang.

c. Bagaimana tingkat keakuratan Cost Significant Model terhadap biayaa ktual proyek.

Penelitian ini bertujuan untuk mengembangkan suatu model estimasi biaya yang dapat memberikan informasi biaya awal proyek dengan cepat, mudah dan dengan hasil yang cukup akurat.

\section{Metode Penelitian}

Menurut Iman Soeharto (1995), estimasi biaya proyek memegang peranan penting dalam penyelenggaraan proyek. Pada tahap awal estimasi biaya dipergunakan untuk mengetahui berapa besar biaya yang dibutuhkan untuk membangun suatu proyek.

Menurut Brahmana (2009), Analisis regresi linier berganda adalah analisis regresi untuk menggambarkan suatu persoalan (variable terikat) yang dipengaruhi oleh lebih dari satu factor (variable bebas). Tujuan analisis regresi linier berganda adalah untuk mengukur intensitas hubungan antara dua variable atau lebih dan membuat prediksi perkiraan nilai $\mathrm{Y}$ atas $\mathrm{X}$.

Model regresi linier berganda:

$$
Y=a_{0}+a_{1} X_{1}+a_{2} X_{2}+a_{3} X_{3}+\ldots . .+a_{n} X_{n}
$$

Analisis Estimasi Biaya Dengan Metode Cost Significant Model Sebagai Dasar Perhitungan Konstruksi Jembatan Beton Bertulang Di Kabupaten Aceh Tamiaang Khamistan 
Keterangan:

$\begin{array}{ll}Y & =\text { taksiran bagi variable terikat } \mathrm{Y} \\ \mathrm{a}_{0} & =\text { taksiran parameter konstanta } \mathrm{a}_{0} \\ \mathrm{a}_{1}, \mathrm{a}_{2}, \mathrm{a}_{3}, \ldots, \mathrm{a}_{\mathrm{n}} & =\text { taksiran parameter koefisien regresi } \mathrm{a}_{1}, \mathrm{a}_{2}, \mathrm{a}_{3}, \ldots, \mathrm{a}_{\mathrm{n}} \\ \mathrm{X}_{1}, \mathrm{X}_{2}, \mathrm{X}_{3}, \mathrm{X}_{\mathrm{n}} & =\text { nilai variable bebas }\end{array}$

Menurut Visiyo Desma Falahis (2015), Cost Significant Model adalah suatu model estimasi biaya yang menggunakan biaya pekerjaan yang secara signifikan berpengaruh terhadap biaya total proyek. Cost Significant Model menggunakan data dari proyek-proyek sejenis yang telah dilaksanakan sebelumnya.

Klasifikasi tingkat keakuratan estimasi berdasarkan tahap dalam proyek serta model biaya yang dapat digunakan menurut AACE International (2005) ditunjukkan pada Tabel 1 .

Tabel1 Klasifikasi estimasi biaya menurut AACE International

\begin{tabular}{|c|c|c|c|}
\hline $\begin{array}{c}\text { Estimation } \\
\text { Class }\end{array}$ & $\begin{array}{c}\text { End Usage } \\
\text { (Typical purpose of estimate) }\end{array}$ & $\begin{array}{c}\text { Methodology } \\
\text { (Typical estimating method) }\end{array}$ & $\begin{array}{c}\text { ExpectedAccuracy Range } \\
\text { (Typicall o wand high range) }\end{array}$ \\
\hline \multirow[t]{2}{*}{ Class 5} & \multirow{2}{*}{ Concept Screening } & Capacity Factored, Parametric & Low: $-20 \%$ to $-50 \%$ \\
\hline & & Models, Judgment, or Analogy & High: $+30 \%$ to $+100 \%$ \\
\hline \multirow[t]{2}{*}{ Class 4} & \multirow{2}{*}{ Study or Feasibility } & Equipment Factored or Parametric & Low: $-15 \%$ to $-30 \%$ \\
\hline & & Models & High: $+20 \%$ to $+50 \%$ \\
\hline \multirow[t]{2}{*}{ Class 3} & \multirow{2}{*}{$\begin{array}{c}\text { Budget,Authorization, or } \\
\text { Control }\end{array}$} & Semi-Detailed Unit Cost with & Low: $-10 \%$ to $-20 \%$ \\
\hline & & Assembly Leve lLine Items & High: $+10 \%$ to $+30 \%$ \\
\hline \multirow[t]{2}{*}{ Class 2} & \multirow{2}{*}{ ControlorBid/Tender } & Detailed Unit Cost with Forced & Low: $-5 \%$ to $-15 \%$ \\
\hline & & Detailed Take-Off & High: $+5 \%$ to $+20 \%$ \\
\hline \multirow[t]{2}{*}{ Class 1} & \multirow{2}{*}{ Check Estimate orBid/Tender } & Detailed Unit Cost with Detailed & Low: $-3 \%$ to $-10 \%$ \\
\hline & & Take-Off & High: $+3 \%$ to $+15 \%$ \\
\hline
\end{tabular}

Sumber: Christensen dan Dysert (2005)

Menurut Poh dan Horner (1995), bahwa berlandaskan pada data dan informasi, dengan $20 \%$ materi pekerjaan yang paling mahal termuat dalam $80 \%$ dari nilai total biaya proyek. Dengan mengandalkan data dari proyek yang memiliki ciri-ciri yang sejenis, dimungkinkan akan memiliki materi-materi cost significant yang sama.

Metode Cost Significant Model yang digunakan dengan mendasarkan pada analisa data proyek yang lalu, mempunyai langkah-langkah sebagi berikut:

a. Tidak mengikut sertakan sub pekerjaan yang terkadang jumlahnya cukup besar namun tidak setiap pekerjaan ada.

b. Mengelompokkan sub-sub pekerjaan di mana penggabungan sub pekerjaan bias dilaksanakan apabila pekerjaan tersebut mempunyai satuan ukuran yang sama, harga satuannya tidak berbeda secara signifikan, atau bias menggambarkan operasi kerja lapangan.

c. Menghitung pengaruh time value terhadap harga-harga sub pekerjaan.

Analisis Estimasi Biaya Dengan Metode Cost Significant Model Sebagai Dasar Perhitungan Konstruksi Jembatan Beton Bertulang Di Kabupaten Aceh Tamiaang - 
d. Mencari cost-significant items, yang diidentifikasi sebagai sub-sub pekerjaan terbesar yang jumlah prosentasenya sama atau lebih besar dari $80 \%$ total biaya proyek.

e. Membuat model biaya dari cost significant items yang telah ditentukan.

f. Mencari rata-rata Cost Model Factor (CMF). CMF didapatkan dengan cara membagi nilai proyek yang didapatkan dari model dengan nilai actual proyek.

g. Menghitung estimasi biaya proyek dari Cost Significant Model, dengan cara membagi nilai proyek yang diprediksi dari model dengan rata-rata CMF.

h. Menghitung akurasi model dalam bentuk prosentase dari selisih antara harga yang diprediksi dengan harga sebenarnya dibagi dengan harga sebenarnya dengan persamaan (Poh\& Horner, 1995).

Kelebihan dari metode Cost Significant Model adalah dapat memprediksi biaya proyek dengan mudah, cepat, dan cukup akurat, walaupun belum tersedianya uraian dan spesifikasi pekerjaan. Metode ini dapat digunakan pada tahap-tahap awal proyek seperti pada saat penyusunan konsep, studi kelayakan, dan perencanaan pendahuluan. Sedangkan kelemahannya adalah proyek yang ditinjau harus sama, dibutuhkan data historis proyek yang terdahulu dan akurasi model sangat dipengaruhi oleh baik tidaknya data yang dikumpulkan.

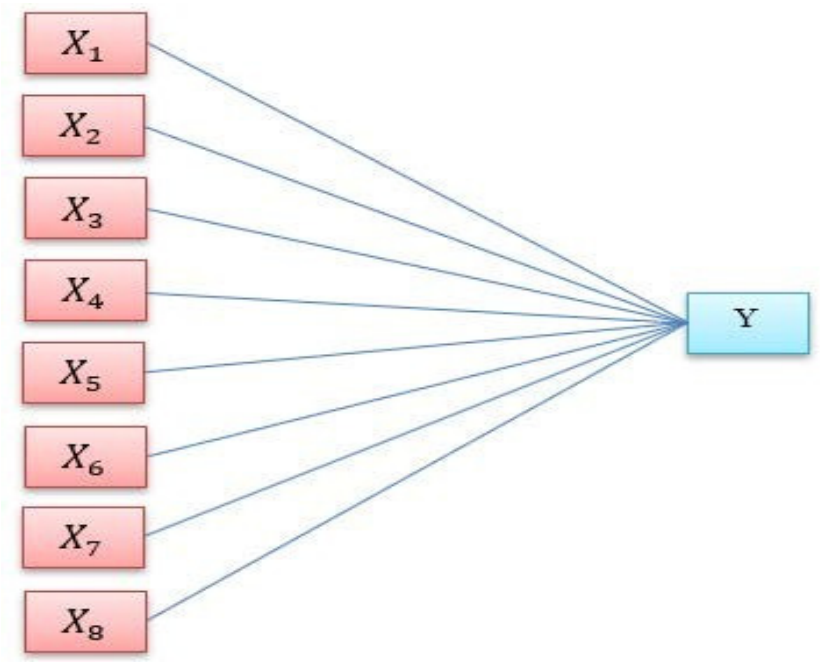

Gambar 1 Hubungan antara variable bebas dengan variable terikat

Keterangan:

$$
\begin{aligned}
& \mathrm{X} 1=\text { Biaya Mobilisasi } \\
& \mathrm{X} 2=\text { Biaya Pekerjaan tanah } \\
& \mathrm{X} 3=\text { Biaya pekerjaan beton } \\
& \mathrm{X} 4=\text { Biaya pekerjaan tulangan } \\
& \mathrm{X} 5=\text { Biaya pondasi } \\
& \mathrm{X} 6=\text { Biaya minor } \\
& \mathrm{X} 7=\text { Biaya pemasangan bangunan atas } \\
& \mathrm{X} 8=\text { Biaya pasangan batu } \\
& \mathrm{Y}=\text { Jumlah nilai pekerjaan/real cost }
\end{aligned}
$$

Analisis Estimasi Biaya Dengan Metode Cost Significant Model Sebagai Dasar Perhitungan Konstruksi Jembatan Beton Bertulang Di Kabupaten Aceh Tamiaang Khamistan 
Penelitian ini menggunakan data sekunder berupa data histori dari proyek yang sejenis yang diperoleh dari dokumen proyek yang sudah ada pada Bidang Bina Marga Dinas Pekerjaan Umum dan Perumahan Rakyat Kabupaten Aceh Tamiang. Adapun paket-paket proyek tersebut terdiri dari dari 5 paket proyek jembatan beton bertulang. Data tersebut dievaluasi dengan menggunakan metode sampling yaitu dengan mengumpulkan data dari sebagian populasi yang dianggap mewakili keseluruhan cirri populasi yang dikehendaki (Sugiyono, 2013). berikut:

Dalam penelitian ini, pengambilan data dilakukan dengan acuan sebagai

a. Data yang diambil berupa Bill of Quantity (Daftar Kuantitas dan Harga) paket jembatan beton bertulang dari tahun anggaran 2013 sampai 2017.

b. Harga komponen biaya dan biaya total yang digunakan merupakan biaya tanpa Pajak Pertambahan Nilai(PPN).

Spesifikasi data yang digunakan berupa identifikasi variable yaitu komponen biaya pekerjaan sebagai variable bebas dan biaya total sebagai variable terikat (Y), yang dapat dijelaskan seperti diperlihatkan pada Gambar 1.

Tahapan analisis data untuk merencanakan estimasi biaya dengan metode Cost Significant Model sebagai berikut:

1. Pengaruh Time Value

Pengaruh time value dapat dihitung berkurangnya nilai uang akibat factor inflasi tiap tahunnya. Perhitungan menggunakan Future Value $(F V)$ dapat dilihat pada persamaan2 (Giatman, 2007):

$$
F=P(1+i) n
$$

Keterangan:

$\mathrm{F}=$ nilai harga pada proyeksi yang ditentukan

$\mathrm{P}=$ harga sebelum diproyeksikan

$\mathrm{i}=$ factor inflasi

$\mathrm{n}=$ tahun proyeksi

2. Proporsi komponen biaya

Proporsi tiap komponen biaya terhadap biaya total dicari dengan menghitung proesentase rata-rata tiap komponen biaya terhadap rata-rata total biaya total proyek.

\section{Cost Significant Items}

Cost Significant Items adalah komponen-komponen biaya terbesar yang menyusun $\geq 80 \%$ biaya total.

4. Uji persyaratan analisis

Uji persyaratan yang harus dipenuhi adalah uji normalitas yaitu data hendaknya memenuhi persyaratan distribusi normal. Uji normalitas dalam penelitian dapat diketahui uji Kolmogorov-Smirnov. Persyaratan data disebut normal jika nilai sig atau probabiltas atau $\mathrm{p}>0,05$, sehingga data yang diuji memenuhi persyaratan normal. 
5. Analisis Data

Dalam penelitian ini analisis data yang digunakan adalah regresi berganda dengan bantuan program SPSS, yaitu pengujian Koefisien korelasi (R), Koefisien determinasi, Uji ANOVA atau uji Fdan Uji t.

- Koefisien korelasi (R)

- Koefisien determinasi

- Uji ANOVA atau uji F

- Uji t

6. Pengujian model

Menurut Poh dan Horner (1995), bahwa pengujian model bias dilakukan dengan cara membagi biaya estimasi model dengan Cost Model Factor (CMF). Merupakan rata-rata rasio dari biaya estimasi model dengan biaya akurasinya dalam bentuk persentase dan dievaluasi secara sederhana sebagai selisih antara harga yang diprediksi dengan yang sebenarnya, sesuai dengan persamaan 3:

$$
\text { Akurasi }=\frac{(E v-A v)}{A v} \times 100 \%
$$

Keterangan:

$\mathrm{Ev}=$ Estiamted bill value (harga yang diprediksi)

$\mathrm{Av}=$ Actual bill value (harga yang sebenarnya)

\section{Hasil dan Pembahasan}

Dari analisis yang dilakukan, dapat diketahui proporsi komponen biaya konstruksi jembatan beton bertulang adalah: mobilisasi $\left(\mathrm{X}_{1}\right)$ sebesar 3,76\%, pekerjaan tanah $\left(\mathrm{X}_{2}\right)$ sebesar $7,05 \%$, pekerjaan beton $\left(\mathrm{X}_{3}\right)$ sebesar $21,33 \%$, pekerjaan tulangan $\left(\mathrm{X}_{4}\right)$ sebesar $37,17 \%$, pekerjaan pondasi $\left(\mathrm{X}_{5}\right)$ sebesar $18,62 \%$, pekerjaan minor $\left(\mathrm{X}_{6}\right)$ sebesar $1,18 \%$, pekerjaan bangunan atas $\left(\mathrm{X}_{7}\right)$ sebesar $1,43 \%$, dan pekerjaan pasangan batu $\left(\mathrm{X}_{8}\right)$ sebesar $3,02 \%$, seperti yang diperlihatkan pada Tabel 2.

Tabel 2 Proporsi komponen biaya

\begin{tabular}{llcrrr}
\hline No. & \multicolumn{1}{c}{ Uraian } & Simbol & \multicolumn{1}{c}{$\begin{array}{c}\text { Mean } \\
(\mathbf{R p})\end{array}$} & $\begin{array}{c}\text { Std.Deviasi } \\
(\mathbf{R p})\end{array}$ & $\%$ \\
\hline 1 & JumlahBiaya & $\mathrm{Y}$ & $103.772 .166,77$ & $26.622 .504,88$ & 100,00 \\
\hline 2 & Mobilisasi & $\mathrm{X} 1$ & $3.904 .998,30$ & $1.603 .744,94$ & 3,76 \\
\hline 3 & PekerjaanTanah & $\mathrm{X} 2$ & $7.314 .990,60$ & $6.904 .455,81$ & 7,05 \\
\hline 4 & PerkerasanBeton & $\mathrm{X} 3$ & $22.139 .214,42$ & $10.599 .638,44$ & 21,33 \\
\hline 5 & PekerjaanTulangan & $\mathrm{X} 4$ & $38.574 .483,69$ & $15.205 .241,03$ & 37,17 \\
\hline 6 & PekerjaanPondasi & $\mathrm{X} 5$ & $19.325 .328,73$ & $4.155 .632,41$ & 18,62 \\
\hline 7 & PekerjaanMinor & $\mathrm{X} 6$ & $1.224 .169,15$ & $546.584,57$ & 1,18 \\
\hline 8 & PemasanganBangunanAtas & $\mathrm{X} 7$ & $1.483 .827,05$ & $1.321 .714,01$ & 1,43 \\
\hline 9 & PasanganBatu & $\mathrm{X} 8$ & $3.135 .854,55$ & $1.364 .453,62$ & 3,02 \\
\hline
\end{tabular}

Analisis Estimasi Biaya Dengan Metode Cost Significant Model Sebagai Dasar Perhitungan Konstruksi Jembatan Beton Bertulang Di Kabupaten Aceh Tamiaang - 
Adapun rata-rata proporsi komponen biaya per $\mathrm{m}$, dari komponen terbesar sampai terkecil ditampilkan dalam bentuk grafik seperti pada Gambar 2 (Riduwan, 2013)

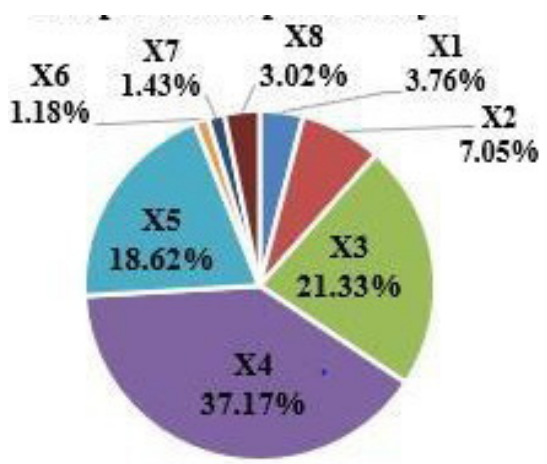

Gambar 2 Proporsi komponen biaya per m

Proporsi masing-masing komponen biaya seperti pada Tabel 2, selanjutnya diurut dari yang terbesar sampai terkecil.Cost Significant Items diidentifikasi sebagai item-item terbesar yang jumlah prosentasenya sama atau lebh besar dari $80 \%$ jumlah biaya.Hasil dari Tabel 2 memperlihatkan 4 (empat) Cost Significant Items yang memiliki biaya komulatif $(81,68 \%)$ dari total biaya yaitu:

- Pekerjaan tulangan (X4),

- Pekerjaan beton (X3),

- Pekerjaan pondasi (X5), dan

- Pekerjaan tanah (X2).

Variabel bebas diidentifikasi sebagai Cost Significant Items inilah yang selanjutnya akan dianalisis dengan menggunakan program SPSS.

Tabel 3 Uji normalitas

\begin{tabular}{llrrrrr}
\hline & & $\begin{array}{c}\text { Pekerjaan } \\
\text { Tulangan }\end{array}$ & $\begin{array}{c}\text { Pekerjaan } \\
\text { Beton }\end{array}$ & $\begin{array}{c}\text { Pekerjaan } \\
\text { Pondasi }\end{array}$ & $\begin{array}{c}\text { Pekerjaan } \\
\text { Tanah }\end{array}$ & Biaya Total \\
\hline N & & 5 & 5 & 5 & 5 & 5 \\
Normal Parameters ${ }^{\mathrm{a}, \mathrm{b}}$ & Mean & $38.574 .483,69$ & $22.139 .214,42$ & $19.325 .328,73$ & $7.314 .990,59$ & $103.772 .166,77$ \\
& Std. Deviation & $15.205 .241,03$ & $10.599 .638,43$ & $4.155 .632,14$ & $6.904 .455,81$ & $26.622 .504,88$ \\
Most Extreme Differences & Absolute & .265 & .359 & .250 & .226 & .267 \\
& Positive & .265 & .359 & .250 & .226 & .267 \\
& Negative & -.175 & -.212 & -.213 & -.161 & -.167 \\
Test Statistic & & .265 & .359 & .250 & .226 & .267 \\
Asymp. Sig. (2-tailed) & & $.200^{\mathrm{c}, \mathrm{d}}$ & $.034^{\mathrm{c}}$ & $.200^{\mathrm{c}, \mathrm{d}}$ & $.200^{\mathrm{c}, \mathrm{d}}$ & $.200^{\mathrm{c}, \mathrm{d}}$ \\
\hline
\end{tabular}

Tabel 3 memperlihatkan hasil uji normalitas yang berdasarkan uji Kolmogorv-Smirnov dengan tingkat signifikansi masing-masing variable lebih besar dari yang disyaratkan, yaitu 0,05 hal ini menyatakan H0 diterima yang

Analisis Estimasi Biaya Dengan Metode Cost Significant Model Sebagai Dasar Perhitungan Konstruksi Jembatan Beton Bertulang Di Kabupaten Aceh Tamiaang - 
berarti data residual terdistribusi normal. Tetapi pada variable X3, tingkat signifikansi lebih rendah dari yang disyaratkan sehingga data residual tidak normal. Pada Gambar 3. Grafik normal P-P Plot terlihat titik menyebar disekitar garis diagonal. Jika menyebar di sekitar garis diagonal, maka regresi memuhi asumsi normalitas.

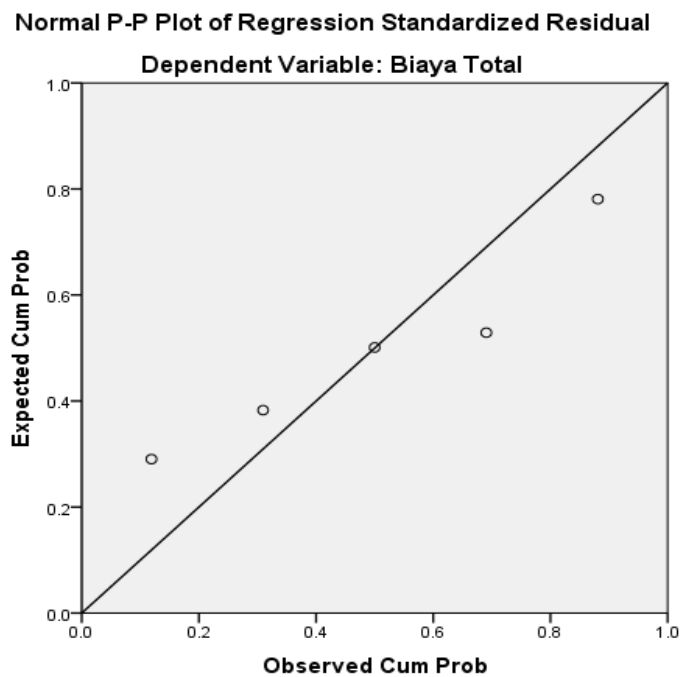

Gambar 3 Grafik normal P-P plot

Pada Tabel 4, hasil analisis dengan SPSS menunjukkan angka koefisien determinasi $\left(\mathrm{R}^{2}\right)=0,99996$ menunjukkan bahwa $99,96 \%$ biaya $(\mathrm{Y})$ dipengaruhi oleh factor $X_{4}, X_{5} \quad$ dan $X_{2}$. Sedangkan sisanya $(100 \%-99,96 \%)=0,004 \%$ dipengaruhi oleh factor lain.

Tabel 4 Model summary ${ }^{\mathrm{b}}$

\begin{tabular}{lrrrr}
\hline Model & R & R Square & $\begin{array}{l}\text { Adjusted } \\
\text { R Square }\end{array}$ & $\begin{array}{c}\text { Std Error Of The } \\
\text { Estimate }\end{array}$ \\
\hline 1 & $1.000^{\mathrm{a}}$ & 0.99999 & 0.99996 & 502004.1586 \\
\hline
\end{tabular}

Sedangkan pada Tabel 5, uji ANOVA atau uji $\mathrm{F}$ menunjukkan tingkat signifikansi $0,012<0,05$, maka model regresi bias digunakan untuk memprediksi biaya (Riduwan, 2008).

Tabel 5 Anova

\begin{tabular}{llrrrrr}
\hline Model & & \multicolumn{1}{c}{ Sum of Squares } & df & Mean Square & F & Sig \\
\hline 1 & Regression & 2834779056664017.000 & 3 & 944926352221339.000 & 3749.586 & $-0.12^{\text {b }}$ \\
\hline & Residual & 252008175267.025 & 1 & 252008175267.025 & & \\
\hline & Total & 2835031064839284.000 & 4 & & & \\
\hline
\end{tabular}

Analisis Estimasi Biaya Dengan Metode Cost Significant Model Sebagai Dasar Perhitungan Konstruksi Jembatan Beton Bertulang Di Kabupaten Aceh Tamiaang - 
Selanjutnya dengan melakukan analisis regresi dari ketiga variable independent diperoleh persamaan regresi $\mathrm{Y}=-19.832 .201,418+1,948 \mathrm{X}_{1}$ $+0,889 \mathrm{X}_{2}+4,274 \mathrm{X}_{3}$. dimana $\mathrm{Y}$ adalah biaya pembangunan jembatan $(\mathrm{Rp} / \mathrm{m}), \mathrm{X}_{1}$ adalah biaya pekerjaan tulangan $(\mathrm{Rp} / \mathrm{m}), \mathrm{X}_{2}$ adalah biaya pekerjaan pondasi $(\mathrm{Rp} / \mathrm{m})$, dan $\mathrm{X}_{3}$ adalah biaya pekerjaan tanah $(\mathrm{Rp} / \mathrm{m})$.

Tabel 6 Coefficients

\begin{tabular}{llrrrrr}
\hline \multirow{2}{*}{ Model } & \multicolumn{2}{c}{ Unstandardized Coefficients } & \multicolumn{2}{c}{$\begin{array}{c}\text { Standardized } \\
\text { Coefficients }\end{array}$} & \multirow{2}{*}{ t } & \multicolumn{1}{c}{ sig } \\
\cline { 2 - 4 } & \multicolumn{1}{c}{ B } & \multicolumn{1}{c}{ Std Error } & Beta & & \\
\hline 1 & (Constant) & -19832201.418 & 4661091.569 & & -4.255 & .147 \\
& Pekerjaan Tulangan & 1.948 & .045 & 1.113 & 43.222 & .015 \\
& Pekerjaan Pondasi & .889 & .145 & .139 & 6.138 & .103 \\
& Pekerjaan Tanah & 4.274 & .050 & 1.109 & 85.776 & .007 \\
\hline
\end{tabular}

Model persamaan regresi yang didapat, diperlukan pengujian terhadap penyimpangannya. Menurut Poh dan Horner (1995), pengujian terhadap penyimpangan model dapat dilakukan dengan cara membagi jumlah nilai proyek yang telah diprediksi, dengan nilai Cost Model Factor (CMF). Sedangkan CMF merupakan rasio dari total biaya yang diestimasi berdasarkan model yang telah diperoleh, dengan total biaya proyek sebenarnya, seperti yang ditunjukkan pada Tabel 7.

Tabel7. HasilperhitunganCost Model Factor

\begin{tabular}{|c|c|c|c|c|c|c|c|}
\hline \multirow[t]{2}{*}{$\mathrm{NO}$} & \multirow[t]{2}{*}{$\begin{array}{c}\text { NAMA } \\
\text { JEMBATAN }\end{array}$} & $\begin{array}{c}\text { HARGAPERM } \\
\text { BETON }\end{array}$ & $\begin{array}{l}\text { HARGAPERM } \\
\text { TULANGAN }\end{array}$ & $\begin{array}{l}\text { HARGAPERM } \\
\text { PONDASI }\end{array}$ & $\begin{array}{c}\text { BIAYA } \\
\text { ESTIMASI } \\
\text { MODELPER } \\
\text { MBENTANG }\end{array}$ & $\begin{array}{c}\text { BIAYA } \\
\text { AKTUALPER } \\
\text { MBENTANG } \\
\text { JEMBATAN }\end{array}$ & \multirow[t]{2}{*}{$\mathrm{CMF}$} \\
\hline & & $(\mathrm{Rp} / \mathrm{m})$ & $(\mathrm{Rp} / \mathrm{m})$ & $(\mathrm{Rp} / \mathrm{m})$ & $(\mathrm{Rp} / \mathrm{m})$ & $(\mathrm{Rp} / \mathrm{m})$ & \\
\hline (1) & (2) & (3) & (4) & (5) & (6) & (7) & (8) \\
\hline 1 & GunungPandan & $40.600 .896,55$ & $12.159 .772,07$ & $380.691,29$ & $71.695 .457,01$ & $75.371 .008,94$ & 0,9512 \\
\hline 2 & Seumadam & $30.412 .950,67$ & $22.122 .160,75$ & $2.244 .215,14$ & $68.670 .602,90$ & $69.463 .243,80$ & 0,9886 \\
\hline 3 & AlurSelebu & $26.339 .337,33$ & 22.141 .012 .01 & $8.277 .257,34$ & $86.537 .185,24$ & $87.679 .555,04$ & 0,9870 \\
\hline 4 & BaboII & $57.087 .969,14$ & $14.452 .198,09$ & $6.714 .532,62$ & $132.921 .078,96$ & $133.696 .392,79$ & 0,9942 \\
\hline 5 & SukaRamaiII & $24.349 .046,21$ & $20.354 .450,87$ & $18.156 .398,99$ & $123.295 .296,70$ & $123.161 .190,93$ & 1,0011 \\
\hline \multicolumn{7}{|c|}{ Rata-RataCMF } & 0,9844 \\
\hline
\end{tabular}

Hasil estimasi Cost Significant Model yang didapatkan dari perbandingkan biaya model estimasi proyek yang ditinjau dengan rata-rata Cost Model Factor. Tingkat akurasinya adalah dengan menghitung selisih dari estimasi Cost Significant Model dengan biaya total pelaksanaan (biaya aktual), dibagi dengan biaya total pelaksanaan dan dikali $100 \%$. Sebagai perbandingan, dihitung juga akurasi metode yang selama ini digunakan yaitu metode parameter bentang jembatan terhadap metode Cost Significant Model.

Analisis Estimasi Biaya Dengan Metode Cost Significant Model Sebagai Dasar Perhitungan Konstruksi Jembatan Beton Bertulang Di Kabupaten Aceh Tamiaang - 
Tabel 8 Komparasi model estimasi biaya pembangunan jembatan

\begin{tabular}{|c|c|c|c|c|c|c|}
\hline \multirow{2}{*}{ No } & \multirow{2}{*}{$\begin{array}{l}\text { NAMA PAKET } \\
\text { PROYEK }\end{array}$} & \multirow{2}{*}{$\begin{array}{l}\text { BIAYATOTAL } \\
\text { PELAKSANAAN }\end{array}$} & \multicolumn{2}{|c|}{ COST SIGNIFICANT MODEL } & \multicolumn{2}{|c|}{$\begin{array}{l}\text { METODE PARAMETER } \\
\text { PANJANG JEMBATAN }\end{array}$} \\
\hline & & & $\begin{array}{c}\text { ESTIMASI } \\
\text { BIAYA }\end{array}$ & AKURASI & $\begin{array}{l}\text { ESTIMASI } \\
\text { BIAYA }\end{array}$ & AKURASI \\
\hline & & $(\mathrm{Rp})$ & $(\mathrm{Rp})$ & & $(\mathrm{Rp})$ & \\
\hline 1 & Gunung Pandan & $3.014 .840 .357,57$ & $2.913 .215 .607,54$ & $-3,37 \%$ & 3.500 .000 .000 & $16,09 \%$ \\
\hline 2 & Seumadam & $2.014 .434 .070,21$ & $2.022 .971 .933,80$ & $0,42 \%$ & 2.325 .000 .000 & $15,42 \%$ \\
\hline 3 & Alur Selebu & $438.397 .775,22$ & $439.535 .308,79$ & $0,26 \%$ & 500.000 .00 & $14,05 \%$ \\
\hline 4 & Babo II & $2.673 .927 .855,76$ & $2.700 .504 .173,78$ & $0,99 \%$ & 3.088 .000 .000 & $15,49 \%$ \\
\hline \multirow[t]{4}{*}{5} & Suka Ramai II & $862.128 .336,48$ & $876.729 .357,65$ & $1,69 \%$ & 972.900 .000 & $12,85 \%$ \\
\hline & & Max & & $1,69 \%$ & & $16,09 \%$ \\
\hline & & Min & & $-3,37 \%$ & & $12,85 \%$ \\
\hline & & Rata-Rata & & $0,00 \%$ & & $14,78 \%$ \\
\hline
\end{tabular}

Berdasarkan hasil dari pengujian model dengan pada Tabel 8, didapatkan akurasi dengan Cost Significant Model berkisar antara-3,57\% sampai dengan $+1,69 \%$ dengan rata-rata $+0,00 \%$. Sedangkan dengan metode parameter Panjang jembatan yang selama ini digunakan pada Bidang Bina Marga Dinas Pekerjaan Umum dan Perumahan Rakyat Kabupaten Aceh Tamiang, berkisar antara $+16,09 \%$ sampai dengan $+12,85 \%$, dengan rata-rata $+14,78 \%$.

Estimasi biaya dengan Cost Significant Model yang dikembangkan menghasilkan estimasi yang lebih baik dibandingkan dengan menggunakan parameter Panjang jembatan. Berdasarkan klasifikasi AACE International tingkat keakuratan estimasi Cost Significant Model berada di kelas 1 dan cocok untuk pemeriksaan perkiraan penawaran.

\section{Kesimpulan dan Saran}

\subsection{Kesimpulan}

Berdasarkan hasil penelitian yang telah dilaksanakan, dapat diperoleh kesimpulan sebagai berikut:

1. Model di atas dapat menjelaskan pekerjaan tulangan $\left(\mathrm{X}_{4}\right)$, pekerjaan pondasi $\left(\mathrm{X}_{5}\right)$ dan pekerjaan tanah $\left(\mathrm{X}_{2}\right)$ berpengaruh sebesar $99,996 \%$ dari biaya total proyek, dan sisanya $0,004 \%$ dipengaruhi oleh sebab-sebab lain.

2. Model estimasi biaya pembangunan jembatan beton bertulang di Kabupaten Aceh Tamiang dengan Cost Significant Model sebagai berikut:

$\mathrm{Y}=-19.832 .201,418+1,948 \mathrm{X}_{1}+0,889 \mathrm{X}_{2}+4,274 \mathrm{X}_{3}$

3. Tingkat keakuratan model estimasi berkisar antara-3,37\% sampai dengan $+1,69 \%$, dengan rata-rata $+0,00 \%$. Tingkat keakuratan tersebut berada di kelas 1 Klasifikasi AACE International yang memiliki batas bawah $-3 \%$ sampai $-10 \%$ dan batas atas $+3 \%$ sampai $+15 \%$. Model estimasi layak digunakan untuk pemeriksaan perkiraan penawaran.

Analisis Estimasi Biaya Dengan Metode Cost Significant Model Sebagai Dasar Perhitungan Konstruksi Jembatan Beton Bertulang Di Kabupaten Aceh Tamiaang - 
4. Estimasi dengan Cost Significant Model menghasilkan estimasi yang lebih baik bila dibandingkan dengan estimasi menggunakan parameter Panjang jembatan yang selama ini digunakan yang akurasinya berkisar antara $+16,09 \%$ sampai dengan $+12,85 \%$, dengan rata - rata $+14,78 \%$.

\subsection{Saran}

Pada penelitian ini dapat diberikan saran-saran sebagai rekomendasi untuk penelitian lanjutan sebagai berikut:

1. Model dapat diperluas dengan pekerjaan yang lebih kompleks dengan jumlah data yang lebih banyak

2. Dalam pekerjaan proyek pemerintah hendaknya dianalisis terlebih dahula dengan CSM agar dapat dilakukan efisiensi biaya dan waktu.

\section{Daftar Kepustakaan}

Brahmana, Agus Efrata. 2009, Analisis Regresi Berganda Terhadap Faktor-faktor yang Mempengaruhi Laju Inflasi Tahun 2006-2007. Universitas Sumatera Utara. Medan.

Christensen, Peter dan Dysert, Larry , 2005, AACE International Recommended Practice No. 18R-97 Cost Estimate Classification System - As Applied in Engineering, Procurement, and Construction for the Process Industries TCM Framework:7.3 - Cost Estimating and Budgeting), AACE,Inc.

Giatman, 2007, EkonomiTeknik, Raja Grafindo Persada, Jakarta

Poh, Paul S.H. dan Horner, R. Malcom W, 1995, Cost-Significant Modelling - Its Potential for Usein South-eastAsia, Engineering, Construction and Architectural Management. Vol. 2 Iss:2. Pp. 121-139.

Riduwan, 2008, Rumusan dan data dalamaplikasistatistika, Alfabeta, Bandung

Riduwan, 2013, Skala Pengukuran Variabel-variabel Penelitian, Alfabeta, Bandung

Santoso, Singgih, 2014, SPSS 18 From Essential to Expert Skill, PT. Elex Media Komputindo, Jakarta

Soeharto, Iman, 1995, Manajemen Proyek Dari Konseptual Sampai Operasional, Erlangga, Jakarta

Sugiyono, 2013, Metode Penelitian Kualitatif, Kuantitatif dan R\&D, Alfabeta, Bandung.

Visiyo, Desma, Falahis, 2015, Cost Significant Model Sebagai Dasar Permodelan Estimasi Biaya Konstruksi Jembatan Beton Bertulang, e-JurnalMatriks Teknik Sipil, Universitas Sebelas Maret, Surakarta. 